\title{
PENTINGNYA PENGEMBANGAN GEOGRAPHY VIRTUAL LABORATORY (GEO V-LAB) SEBAGAI MEDIA PEMBELAJARAN LITOSFER
}

\author{
Pradika Adi Wijayanto, \\ Muhammad Fatkhur Rizal, \\ Elok Ayu Khumaerok Ertika Subekti, \\ Tiara Annisa Novianti \\ Universitas Negeri Malang \\ E-mail: annisat95@gmail.com
}

\begin{abstract}
Abstrak
Laboratorium geografi sangat dibutuhkan dalam kegiatan pembelajaran di Sekolah Menengah Atas (SMA). Keberadaan laboratorium geografi rill dan alami mampu menunjang proses pembelajaran geografi pada materi litosfer menjadi aktif, efektif, serta menyenangkan. Pengadaan laboratorium geografi di SMA memiliki kendala terkait biaya, peningkatan kompetensi profesional pendidik dalam memanajemen laboratorium, serta kurangnya partisipasi dari berbagai pihak. Kendala tersebut dapat diminimalisir dengan mengembangkan geography virtual laboratory yang berguna untuk mengatasi keterbatasan dalam penyediaan laboratorium geografi rill dan alam. Kajian ini membahas pentingnya pengembangan geography virtual laboratory (GEO V-LAB) yang bermanfaat sebagai media pembelajaran materi litosfer yang praktis, efektif meningkatkan pemahaman konstekstual siswa, menanamkan nilai-nilai pendidikan karakter, menghemat waktu dan biaya. Memenuhi hal tersebut maka pengembangannya diharapkan menjadi solusi alternatif pihak Sekolah.
\end{abstract}

Kata Kunci: Pengembangan, Geography Virtual Laboratory, Media, Pembelajaran, Litosfer

\begin{abstract}
Geography laboratory is needed in the learning activities at Senior High School (SMA). The existence of a laboratory of natural and natural geography able to support the process of geography learning on lithosphere material to be active, effective, and fun. The procurement of geography laboratories in SMA has cost related constraints, increased professional competence of educators in laboratory management, and lack of participation from various parties. These constraints can be minimized by developing a virtual laboratory geography that is useful to overcome the limitations in the provision of laboratory geography of nature and nature. This study discusses the importance of the development of virtual laboratory geography (GEO V-LAB) which is useful as a learning media of practical lithosphere materials, effectively improving students' contextual understanding, instilling character education values, saving time and cost, Fulfilling it is expected to be the solution school alternative.
\end{abstract}

Keywords: Development, Geography Virtual Laboratory, Media, Learning, Litosphere

\section{PENDAHULUAN}

Objek material geografi mengkaji ilmu dengan menitikberatkan pada karakteristik unik dari suatu fenomena secara luas untuk dipelajari. Objek material tersebut menurut Bintarto dalam Suharsono \& Budi (Suharsono \& Budi, 2006) adalah objek bersifat umum dan luas, yaitu geosfer meliputi litosfer, atmosfer, hidrosfer, biosfer, pedosfer, antroposfer. Litosfer merupakan salah satu objek material geografi yang penting dipelajari sehingga melatarbelakangi adanya pengintegrasian dalam kurikulum 2013 revisi 2017 kelas $\mathrm{X}$ yang tercantum pada Kompetensi Dasar (KD). Mengetahui kompetensi dasar tersebut materi yang dipelajari pastinya berkaitan dengan proses geologi dan geomorfologi dalam pembentukan bumi secara fisik yang lebih difokuskan pada materi dinamika litosfer dan dampaknya terhadap kehidupan. Kegiatan inti dalam mempelajari kompetensi dasar tersebut terdiri dari mengamati, mendiskusikan dan membuat laporan, mengenali masalah dan mengajukan solusi tentang dampak dinamika litosfer.

Proses pembelajaran yang terbatas menggunakan media cetak (buku panduan, modul, gambar, tabel, peta dan bagan) serta video, animasi sebaiknya dilengkapi oleh kegiatan siswa dilaboratorium supaya konsep-konsep dalam materi pembelajaran geografi lebih mudah dipahami dan diaplikasikan kedalam kehidupan nyata 
sehingga memberikan dampak positif dalam kegiatan pembelajaran siswa. Kondisi ini diperkuat dengan penelitian Hasriyanti (Hasriyanti, 2009); Munawarah (Munawarah, 2014); Wulandari (Wulandari, 2012) menunjukkan pemanfaatan laboratorium geografi efektif dalam meningkatkan hasil belajar sehingga jelas betapa pentingnya penyediaan laboratorium geografi. Pendapat tersebut disimpulkan bahwa laboratorium geografi sangat dibutuhkan dalam pembelajaran geografi karena dengan fasilitas tersebut membantu siswa untuk mengidentifikasi, mengeksplorasi serta mengaplikasikan materi berdasarkan objek material geografi tersebut.

Ketersediaan laboratorium rill dan kondisi alam mendukung pembelajaran geografi khususnya materi litosfer. Mewujudkan ketersediaan laboratorium terdapat kendala umum yang mendasari dalam implementasinya, antara lain: (1) faktor biaya. Faktor ini menjadi alasan pokok yang menghambat dalam terwujudnya laboratorium geografi. Faktor biaya penting, sebab hal yang paling mendasari adanya pertimbangan pengadaan laboratorium geografi. Contohnya faktor ini yaitu biaya penyediaan alat peraga, perawatan alat peraga, pendirian ruangan, peningkatan kompetensi profesional pendidik dalam memanajemen laboratorium. (2) tantangan meningkatkan kompetensi profesional pendidik dalam memanajemen laboratorium geografi. Tantangannya tidak semata terfokus pada biaya tetapi untuk mendapatkan pendidik profesional dalam memanajemen laboratorium geografi lebih berperan nyata. Peningkatan kompetensinya berupa mengikuti berbagai pelatihan, berpartisipasi dalam seminar yang relevan dan belajar mandiri dari sumber-sumber referensi yang valid. (3) faktor dukungan dan kerjasama dengan elemen masyarakat. Faktor ini penting dalam mewujudkan ketersediaan laboratorium geografi. Keberadaan faktor ke tiga ini dianggap berpengaruh karena dukungan nyata dari berbagai pihak dapat memberikan sumbangsih yang besar dalam mewujudkan tujuan tersebut. Dukungan yang berikan tidak hanya terbatas moril saja tetapi bantuan secara nyata lebih diprioritaskan Sekolah. Bantuan nyata misalnya dana hibah, sumbangan tenaga dan pikiran para akademisi profesional dapat menunjang proses ketersediaannya. Kendala di atas relevan dengan pendapat Muchlas dalam Kusumaningsih, Iswahyudi \& Susanti (Kusumaningsih, Y.R. Iswahyudi, \& Susanti, 2014) bahwa pengelolaan laboratorium membutuhkan 1) Sumber Daya Laboratorium 2) Manajemen Laboratorium 3) Biaya Praktikum 4) Peningkatan mutu/kompetensi. Kesimpulannya kendala mewujudkan laboratorium geografi tidak menjadi hambatan yang harus ditakuti, tetapi harus dihadapi demi terwujudnya proses pembelajaran yang kontekstual sesuai dengan tuntutan kurikulum 2013.
Tuntutan perkembangan ilmu pengetahuan dan teknologi yang semakin pesat dibidang pendidikan berfikir dan bertindak secara logis untuk meminimalisir problem yang ditimbulkan. Memahami keadaan tersebut perlusolusi inovatif dengan memanfaatkan media berbasis komputer. Keadaan ini diperkuat oleh Mukminan (Mukminan, 2014) menjelaskan pada era global konteks pembelajaran berubah sangat cepat sehingga orang tidak lagi semata-mata menggantungkan pada dunia sekolah atau kampus dalam arti fisik untuk belajar sehingga media pembelajaran virtual (maya) bisa digunakan sebagai alternatif sumber informasi dan sumber belajar (learning resource). Simpulannya perlu inovasi baru dalam dunia pendidikan dengan memanfaatkan media komputer, salah satunya dengan mengembangkan Geography Virtual Laboratory (GEO V-LAB). Mewujudkan Geography Virtual Laboratory (GEO V-LAB), digunakan sebagai penunjang pembelajaran geografi, khususnya materi litosfer.

Ketersediaan Geography Virtual Laboratory (GEO VLAB) sangat penting di setiap sekolah. Cengiz (2010) memperkuat melalui pendapatnya yaitu laboratorium virtual memiliki dampak positif untuk mencapai tujuan pembelajaran dan menutupi peralatan laboratorium yang kurang memadai. Hasil penelitian Yusriyah (Yusriyah, 2008) menyatakan bahwa V-Lab dapat digunakan sebagai pelengkap praktikum secara face to face. Kedua pendapat tersebut dapat disimpulkan bahwa maka Geography Virtual Laboratory (GEO V-LAB) berpotensi dikembangkan dan digunakan untuk membantu proses transfer pengetahuan geografi, meningkatkan pemahaman menambah pengalaman, meningkatkan efektivitas pembelajaran dalam meraih tujuannya. Sebaliknya jika keberadaan sarana laboratorium di Sekolah, tidak ada maka pemahaman siswa akan materi pelajaran akan mudah hilang, sebab siswa tidak belajar secara kontekstual melainkan berangan semata, tanpa adanya pembelajaran yang rill.

\section{PEMBAHASAN}

\section{Geography Virtual Laboratory Menunjang Materi Pembelajaran Litosfer}

Pembelajaran Geografi memiliki ciri khas yang unik pada materi pembelajarannya. Keunikan ini memerlukan sarana dan prasarana untuk memudahkan dalam memahaminya. Sarana dan prasarananya tidak hanya berasal dari pihak Sekolah saja, tetapi juga meningkatkan mutu para pendidik dan ketersediaan sarana dan prasarana lengkap supaya siswa dapat merasakan pengaruh yang signifikan dalam proses pembelajaran demi tujuan pendidikan Nasional. Keberadaan Geography Virtual Laboratory sangat diperlukan sebagai alternatif ketika ketersediaan laboratorium rill dan alam tidak 
dimungkinkan ada di setiap sekolah terutama untuk mendukung materi litosfer yang pada dasarnya merupakan objek kajian geografi. Pertimbangan yang menguatkan asumsi tersebut dilatarbelakangi bahwa materi litosfer dalam geografi adalah: (1) materi litosfer tidak sekedar berupa hafalan sehingga perlu adanya praktek, misalnya pada materi persebaran tanah di Indonesia memiliki banyak variasi berikut keunikan karakteristiknya sehingga apabila siswa hanya menghafal pastinya saat turun kelapangan siswa akan kebingunan menentukan jenis apakah tanah yang sedang diteliti. (2) adanya konsep dan pendekatan geografiyang dintegrasikan materi pembelajaran litosfer memiliki keterbatasan untuk dijelaskan secara verbal maupun disimulasikan guru sehingga membutuhkan cara tertentu untuk memberikan pengalaman kongkret dan bermaknasupaya siswa lebih memahami esensinya, misalnya pada proses vulkanisme dan pengaruh dalam kehidupan yang materi tersebut termasuk sulit dipahami apabila tidak dibarengi dengan gambaran nyata dari proses dan dampaknya dalam kehidupan. (3) kegiatan pembelajaran geografi lebih didominasi didalam kelas (indoor class) daripada diluar kelas (outdoor class) sehingga pendalaman materi masih terbatas dalam suatu pokok pembahasan, contohnya materi persebaran tanah tidak mungkin guru mengajak siswa melakukan pembelajaran diluar kelas karena keterbatasan jenis sampel tanah yang berada disekitar sekolah, apalagi Indonesia memiliki berbagai macam jenis tanah yang tersebar. Geography Virtual Laboratory berperan penting dalam memperkaya pengetahuan siswa meski tidak turun langsung kelapangan. menghindarkan siswa dari miskonsepsi akibat cara penyampaian materi oleh guru sulit dipahami secara utuh maksudnya, contohnya dalam mempelajari karakteristik lapisan bumi yang memiliki berbagai macam perbedaan tentunya guru membutuhkan media penunjang untuk memudahkan pemahaman siswa agartidak salah tafsir.

Pertimbangan di atas disimpulkan bahwa ketersediaan Geography Virtual Laboratory dalam materi litosfer penting karena membantu siswa memahami materi pelajaran secara benar, mendapat pengalaman bermakna dan pengetahuan yang baru. Manfaat lain dari ketersediaan Geography Virtual Laboratory di Sekolah yaitu: (1) menghemat biaya dan mengurangi tingkat resiko terhadap siswa dalam melaksanakan praktikum geografi di laboratorium rill dan alam. Asumsi tersebut diperkuat oleh Mahanta \& Sarma (Mahanta \& Sarma, 2012) bahwa fungsi laboratorium virtual dapat mengurangi resiko praktikum pada tempat yang berbahaya dan meminimalisir biaya yang mahal. (2) berdampak positif dalam mendukung tujuan pembelajaran geografi serta melatih siswa untuk menguasai keterampilan yang dibutuhkan. Argumen di atas dibuktikan dengan hasil penelitian Hamida, Mulyani \& Utami (Hamida, N. Mulyani, \& Utami, 2013) menunjukkan laboratorium virtual dapat mempengaruhi prestasi belajar kognitif. Hasil penelitian Purwati, Yani \& Haris (Purwati, D. Yani, \& Haris, 2015) juga membuktikan bahwa penerapan laboratorium virtual dapat meningkatkan hasil belajar siswa. Hasil penelitian Sumargo \& Yuanita (Sumargo \& Yuanita, 2014) menunjukkan respon siswa bahwa penggunaan laboratorium virtual memudahkan untuk memahami pelajaran, menyelesaikan soal-soal dan tugas yang diberikan guru, serta membuat siswa lebih termotivasi dalam belajar. (3) mendukung pembelajaran aktif dan mengembangkan sikap bekerjasama (kolaboratif) yang lebih intensif. Hasil penelitian Swandi, Hidayah \& Irsan (Swandi, Hidayah, \& Irsan, 2014) menunjukkan terjadi peningkatan aktivitas siswa. (4) memudahkan siswa mempelajari materi pelajaran yang masih abstrak serta dapat menambah pemahaman akan konsep dan pendekatan yang berkaitan dengan objek formal dan material geografi, Asumsi tersebut diperkuat keunggulan laboratorium virtual menurut Sumargo \& Yuanita (Sumargo \& Yuanita, 2014) yang dapat membantu dalam memperjelas konsep abstrak yang tidak bisa dijelaskan secara verbal. Hasil penelitian Swandi, Hidayah \& Irsan (Swandi et al., 2014) menunjukkan adanya meningkatkan pemahaman konsep. (5) Efisien dalam proses pembelajaran dan menghemat waktu. Hal tersebut dikuatkan oleh Kusumaningsih, Iswahyudi \& Susanti (Kusumaningsih et al., 2014) bahwa laboratorium virtual bermanfaat agar proses pembelajaran menarik dan interaktif, jumlah waktu mengajar berkurang, kualitas belajar bisameningkat karena proses belajar mengajar dapat dilakukan di mana saja dan kapan saja. Kesimpulan dari para pendapat sebagai penguatan begitu pentingnya ketersediaan Geography Virtual Laboratory supaya materi litosfer dapat diterima dan dipahami lebih mudah sekaligus membantu guru dalam mengajar.

\section{Tantangan Mewujudkan Ketersediaan Geography Virtual Laboratory dan Integrasinya dalam Materi Litosfer}

Memahami potensi dan manfaat ketersediaan Geography Virtual Laboratory dalam memfasilitasi materi litosfer sangat penting untuk direalisasikan supaya pembelajaran yang dilakukan berdampak positif. Mewujudkan hal tersebut pasti memiliki tantangan tersendiri khususnya di wilayah Indonesia disebabkan banyaknya perbedaan baik pada sumber daya manusia (kompetensi guru dalam pembelajaran geografi, jenjang pendidikan, pengalaman dan prestasi) Selain itu kemapanan birokrasi pendidikan yang menunjang terbentuknya sekolah-sekolah yang memiliki andil dalam peningkatan kualitas fasilitas yang unggul dapat diakui 
masyarakat kebanyakan. Perbedaaan tersebut menyebabkantantangan tersendiri yang perlu diketahui dalam mewujudkan Geography Virtual Laboratory yang dapat memfasilitasi materi litosfer antara lain:

\section{Perbedaan Kualitas Kompetensi Pedagogik Guru Geografi Indonesia}

Perbedaan segi kualitas kompetensi pedagogik guru merupakan sebuah tantangan yang diketahui. Indonesia yang notabene negara kepulauan pastinya memiliki kualitas guru yang beragam pada setiap daerahnya dengan berbagai faktor yang mempengaruhinya. Hal di atas dibuktikan dengan penelitian Suharini (Suharini, 2009) yang menyatakan bahwa kompetensi pedagogik guru geografi di sekolah akreditasi A di Pati (Jawa Tengah) memiliki kriteria baik dan kompetensi pedagogik guru geografi di sekolah akreditasi B memiliki kriteria yang kurang baik.Selain itu dalam penggunaan media pembelajaran ditemukan bahwa sumber bahan ajar yang utama hanya buku paket pelajaran dengan jumlah terbatas bahkan siswa tidak memiliki buku paket sehingga mengandalkan Lembar Kerja Siswa (LKS). Penelitian Nursa'ban, Suparmini \& Setyowati (Nursa'ban, Suparmini, \& Setyowati, 2012) menghasilkan gambaran umum umum pedagogik guru geografi SMA di Kabupaten Bantul (Yogyakarta) adalah cukup. Dalam menyelenggarakan pembelajaran yang mendidik dengan 6 indikator (termasuk dalam penggunaan dan pengembangan media pembelajaran) masih dalam kategori cukup dari penilaian siswa sedangkan dari penilaian kepala sekolah masuk dalam kategori baik. Penelitian Nurwenda, Ningrum \& Yani (Nurwenda, Ningrum, \& Yani, 2016) menyatakan bahwa sebanyak $(85 \%)$ dari guru geografi Se-Kabupaten Bandung tidak memahami mengenai prinsip pembelajaran. Perangkat pembelajaran yang di kembangkan oleh hampir seluruhnya guru yakni berupa bahan ajar cetak, Sumber belajar yang di gunakan oleh guru ( $83 \%$ ) adalah buku dan media pembelajaran infokus digunakan oleh sebagian besar dari guru (79\%) di dalam proses pembelajaran. Berdasarkan fakta yang ditemukan menunjukkan bahwa kualitas guru masih belum mencukupi dalam kompetensi pedagogik terutama dalam indikator yang terkait dengan media pembelajaran dan pemanfaatan teknologi pembelajaran. Kompetensi pedagogik guru yang baik menjadi syarat mutlak untuk membuat, menggunakan dan mengembangkan Geography Virtual Laboratory menjadi media pembelajaran yang efektif dan sesuai dengan tujuan dan indikator pembelajaran geografi, jika kemampuan tersebut tidak dimiliki oleh guru maka akan sulit mewujudkan pembelajaran yang baik.

\section{Perbedaan Standar Layanan Minimal Pendidikan}

Layanan pendidikan di Indonesia masih perlu diperbaiki, kondisi ini diperkuat pendapat Musyaddad (Musyaddad, 2013) yaitu "akhir-akhir ini kita sering mendengar dan melihat di televisi berita tentang sekolahsekolah yang hampir roboh, dan anak-anaknya terpaksa belajar di luar kelas. Miris melihat kondisi layanan pendidikan seperti ini. Permasalahan layanan ini, tidak hanya terjadi di daerah pinggiran kota saja, bahkan sekolah yang berada di ibukota juga mengalami kejadian seperti ini. Kondisi permasalahan ini seharusnya tidak terjadi, apalagi negara ini sudah menganggarkan anggaran pendidikan, terutama terkait standar layanan pendidikan. Anggaran yang diterima tentunya dapat menanggulangi dan mencgah terjadinya masalah-masalah dalam bidang mutu layanan pendidikan tersebut". Permasalahan dari kondisi diatas sering terjadi hal ini membuktikan bahwa perlu adanya perhatian dari semua belah pihak dalam meninjau ulang pelayanan pendidikan di Indonesia.

Peninjauan ulang dan perhatian khusus pemerintah ini sangat diperlukan untuk meningkatkan mutu pendidikan melaui pemerataan fasilitas pendidikan di setiap wilayah Indonesia. Pemerataan fasilitas pendidikan di Indonesia ini sangat penting diperlukan, demi kemajuan pendidikan di Indonesia. Apabila fasilitas pendidikan tidak merata mampu menghambat kemajuan pendidikan. Penghambatan tersebut secara langsung dapat menimbulkan permasalahan baru, misalnya menghambat sebuah ide dan inovasi-inovasi dalam dunia pendidikan. Contohnya pembuatan Geography Virtual Laboratory sulit untuk dikembangkan jika sekolah belum mempunyai fasilitas yang memadai.

\section{Karakteristik Geografi Memiliki Objek Material yang Banyak.}

Tantangan yang harus diperhatikan dalam mengembangkan Geography Virtual Laboratory adalah karakteristik geografi itu sendiri yang memiliki objek material yang banyak. Diperkuat oleh Bintarto (Bintarto, 1988) bahwa "Objek material geografi merupakan objek yang umum dan luas, yaitu geosfer, meliputi litosfer, atmosfer, hidrosfer, biosfer, pedosfer, antroposfer kemudian melahirkan studi kekhususan, yang dipandang wajar". Geografi mempunyai banyak objek material karena geografi membahas fenomena keruangan, kelingkungan dan kewilayahan.

Objek material pada pembelajaran geografi disajikan dari beberapa kompetensi dasar, contohnya litosfer disajikan dalam 1 kompetensi dasar, padahal dalam pembuatan laboratorium virtual harus memiliki tingkat kedetailan yang tinggi dan mengikuti hukum alam yang berlaku. Kesimpulannya dalam pembuatan Geography Virtual Laboratory membutuhkan banyak tema-tema, 
sehingga tidak bisa hanya memicu dalam satu kompetensi dasar saja, melainkan perlu ada pengambungan dari beberapa tema kompetensi dasar. Penggabungan banyak tema dalam pembuatan Geography Virtual Laboratory ini dimaksudkan untuk memudahkan siswa dalam memahami materi dan objek kajian geografi itu sendiri. Tujuan dari penggabungan tema yaitu mengarah objek kajian geografi tidak akan terlepas dari kajian material dan kajian formalnya. Kedua kajian tersebut tidak dapat dipisahkan, sebab keduanya akan menghasilkan keilmuan geografi dan keilmuan eksakta. Perbedaan keilmuan eksakta dapat disimulasikan dengan konsep yang sederhana. Kondisi ini berbeda dengan geografi yaitu satu simulasi mengenai objek material geografi belum dapat dikatakan mampu menguasai dari keilmuaan geografi secara penuh, jika dimulai dengan sebuah peristiwa geografi maka dapat mewakili dari objek kajian formal dan material. Pembuatan Geography Virtual Laboratory akan mengalami kesulitan sebab harus menyediakan sangat banyak kemungkinan untuk satu fenomena saja. Objek material fisik mengarah pada objek yang dapat disimulasikan dengan relevan, sementara untuk objek material sosial masih terbatas pada teori yang ada sementara dalam kenyataannya belum tentu sama.

Materi litosfer dalam kurikulum 2013 revisi tahun 2017 dinamika litosfer dan dampaknya terhadap kehidupan memiliki materi pembelajaran yang banyak. Setiap materi mempunyai bidang keilmuan masingmasing yang cukup luas. Pembuatan Geography Virtual Laboratory harus berdasarkan pada suatu materi yang mempunyai batas kejadian pada suatu proses rill tertentu yang spesifik, misalnya: pada proses letusan gunung api tipe hawaian maka dalam membentuk Geography Virtual Laboratory harus dibatasi dengan tema tersebut. Materi pembelajaran litosfer yang banyak dan relevan dapat berpotensi untuk dibuat produk dalam melengkapi Geography Virtual Laboratory supaya memudahkan siswa dalam memahami dan mendalami materi pelajaran secara rill.

\section{Strategi Pengembangan Geography Virtual Laboratory Materi Litosfer}

Strategi Pengembangan Geography Virtual Laboratory materi litosfer diperlukan supaya produk yang dibuat dapat konsisten, bermanfaat, tepat guna dan berkualitas baik dilapangan. Laboratorium virtual yang merupakan satu kesatuan sistem dalam mendukung praktikum dapat dibedakan berdasarkan karakteristiknya. Jaya (Jaya, 2012) berpendapat bahwa laboratorium virtual terdiri dari dua tipe utama yaitu laboratorium simulator. Tipe pertama terdiri dari set model perangkat lunak yang merupakan objek atau sistem yang memiliki tingkat abstraksi tertentu. Kelemahannya adalah masalah keakuratan perilaku simulator dimana sangat sering terjadi perbedaan antara benda nyata dengan model abstrak karenamodel abstrak mempunyai tampilan sederhana sehingga tidak dapat mewakili semua fitur dari objek simulasi. Tipe pertama ini dapat digunakan untuk membantu siswa dalam memahami materi secara dasar. Tipe kedua adalah laboratorium berbasis pada peralatan hardware dengan tampilan nyata baik 2-D maupun 3-D. Jenis laboratorium virtual ini mempunyai sebagian besar kualitas jenis pertama meskipun dalam tampilannya nyata di setiap kelas terdapat rak-rak dengan peralatan yang tidak dapat digunakan dalam pembelajaran jarak jauh serta tidak dapat diakses bagi para siswa sepanjang waktu.

Berdasarkan pendapat tersebut dapat disimpulkan bahwa terdapat perbedaan tipe laboratorium virtual sehingga pengembang dapat memilih salah satunya atau menggabungkan keduanya supaya pengembangan produk Geography Virtual Laboratory yang dihasilkan dapat menimbulkan dampak positif sesuai dengan keinginan. Menghasilkan produk Geography Virtual Laboratory yang berkualitas pengembang disarankan menggunakan strategi seperti di bawah ini:

\section{Menggunakan Model Pengembangan}

Perkembangan dalam dunia pendidikan semakin nampak dengan berbagai hasil penemuan serta kontribusinya didunia sehingga dirasakan oleh semua lapisan masyarakat. Perkembangan tersebut tidak bisa lepas dari sebuah penelitian pengembangan (Research \& Development). Kontribusi berbasis teknologi tersebutmembuat sistem pembelajaran yang konvensional menjadi lebih modern dan praktis sehingga menunjang keefektivitasan serta keberhasilan dalam proses pembelajaran. Keberadaannya dapat dipadukan dengan berbagai macam strategi yang menunjang pembelajaran. Pendapat di atas dikuatkan oleh pendapat Putra (Putra, 2015) bahwa R\&D memberikan sumbangan sangat besar pada inovasi pendidikan dengan memperkenalkan pendidikan berbasis teknologi seperti e-learning serta virtual learning sehingga paradigma dan proses belajar yang awalnya terikat kelas-kelas tradisional yang sangat dibatasi ruang dan waktu menjadi lebih leluasa.

Pengembangan Geography Virtual Laboratory pada materi litosfer otomatis merupakan bagian dari virtual learning sehingga tidak bisa lepas dari pemilihan model desain pengembangan yang tepat karena dengan adanya model tersebut menjadi syarat mutlak dalam penelitian pengembangan (Research \& Development) sehingga memiliki dampak positif dalam menghasilkan produk berupa media pembelajaran yang berkualitas baik sehingga waktu digunakan dapat menciptakan proses pembelajaran yang tepat sesuai dengan kebutuhan. Model desain pengembangan banyak sekali jenisnya seperti model desain sistematik Walter Dick dan Lou Carey 
(Dick \& Carey), model ASSURE dari Robert Heinich dkk, Model Cycle dari Jerold E.Kemp dkk, Model sistem pembelajaran Smith \& Ragan, Model ADDIE, Model Front-End Systematic Design dari A.W. Bates (Pribadi, 2010). Terdapat variasi lain dari model penelitian pengembangan menurut Tegeh, Jampel \& Pudjawan (2014) meliputi model penelitian pengembangan Hannafin dan Peck, Model Borg dan Gall, Model DDD-E (Decide, Design, Develop, Evaluate), Model Bergman dan More, Model Isman. Berbagai model yang disebutkan di atas tidak menutup kemungkinan terdapat variasi lain.

Model penelitian pengembangan yang banyak jenisnya sehingga penulis menyarankan penggunaan model Borg dan Gall dalam proses pembuatan Geography Virtual Laboratory, alasannya dilatarbelakangi oleh langkah-langkah pengembangan model ini lengkap dan sistematis sehingga dapat menghasilkan produk dengan tingkat validasi tinggi dan kualitasnya baik. Langkahlangkahnya mengarah pada langkah perencanaan, pengembangan bentuk awal produk disertai alat evaluasinya setelah itu diadakan uji pendahuluan dan revisi produk, uji lapangan utama dan revisi produk hingga uji lapangan operasional dan revisi produk akhir termasuk penyebaran dan pelaksanaan produk secara massal. Modelnya mempunyai kelebihan untuk mendorong dalam melakukan inovasi mutakhir menyesuaikan kebutuhan setiap waktu karena pembuat harus melalui semua tahap uji dan revisi. Model pengembangan tersebut juga pernah digunakan oleh Jaya (Jaya, 2012) untuk mengembangkan laboratorium virtual untuk memfasilitasi kegiatan praktikum dan pendidikan karakter sehingga layak di pertimbangkan.

\section{Konten Relevan}

Konten yang relevan diperlukan supaya proses pembelajaran sesuai dengan tujuannya sehingga pembuatan Geography Virtual Laboratory hendaknya memperhatikan strategi tersebut. Konten yang dimaksud dalam Geography Virtual Laboratory berupa perpaduan antara materi interaktif, soal, gambar, animasi, video atau media lainnya yang relevan disertai dengan umpan balik sesuai dengan ruang lingkup materi litosfer berdasarkan silabus mata pelajaran geografi sehingga dengan adanya konten tersebut akan mempermudah siswa dalam mempelajari dan memahami penggunaan Geography Virtual Laboratory tersebut. Kondisi lain yang perlu ditekankan adalah isi konten pada Geography Virtual Laboratory tidak bisa lepas dari pendekatan keruangan, pendekatan kelingkungan, pendekatan konteks wilayah sehingga mencerminkan ciri khas geografi itu sendiri.

\section{Kepraktisan.}

Kepraktisan dapat diartikan bagaimana media simulasi mudah digunakan serta dipelajari dimanapun siswa berada dan kapanpun baik secara online maupun offline mengingat jaman sekarang siswa tidak bisa dipisahkan konsumsi akan gadget. Keberadaan Geography Virtual Laboratory akan membuat siswa bersemangat serta berminat dalam mempelajari berbagai materi litosfer. Mengembangkan Geography Virtual Laboratory dalam segi kepraktisannya hendaknya produk tersebut mudah dikelola oleh guru geografi sehingga sewaktu-waktu guru dapat merancang sesuai dengan tujuannya terutama untuk mengetahui perkembangan dan hasil belajar dari siswa itu sendiri supaya dapat melakukan langkah yang diperlukan dalam mengatasi problem yang ditemukan dalam pembelajaran geografi.

\section{PENUTUP}

\section{Simpulan}

Pesatnya pengembangan ilmu pengetahuan dan teknologi menyebabkan cepatnya perubahan diera modern ini. Perubahan inilah yang menyebabkan perlu adanya inovasi baru dalam pemanfaatkan teknologi untuk perkembangan dan kemajuan dunia pendidikan. Dunia pendidikan perlu memanfaatkan hasil dari perkembangan dari ilmu pengetahuan dan teknologi, sebab keberadaannya dapat memudahkan siswadalam memahami materi pembelajaran yang disampaikan secara utuh dan guru lebih dimudahkan dalam pelaksanaan pembelajarannya. Khususnya kebutuhan akan Geography Virtual Laboratory. Geography Virtual Laboratory sangatlah penting diperlukan, demi menjawab tuntutan kurikulum 2013 yang mengarah pada pembelajaran kontekstual yang riil dan alam. Mata pelajaran geografi juga sangat membutuhkan laboratorium geografi, apalagi materi litosfer yang membutuhkan alat peraga sebagai media yang mambantu pemahaman siswadalam memahami materi secara utuh. Keberadaan Geography Virtual Laboratory di sekolah memiliki kendala sebagai tantangannya, misalnya pembiayaan, kurangnya kompetensi guru dalam pengembangan Geography Virtual Laboratory. Kendala tersebut tidaklah menjadi hambatan utama jika semua belah pihak memiliki keinginan untuk bekerjasama dalam pengembangan Geography Virtual Laboratory ini.

\section{Saran}

Menunjang keberhasilan dalam pengembangan Geography Virtual Laboratory maka disarankan kepada pihak sekolah menggunakan strategi yang disarankan, selain itu diharapkan Sekolah juga untuk menjalin kerjasama intensif dengan masyarakat, akademisi \& pemerintah. Guru juga harus mampu menentukan materi yang pas agar Geography Virtual Laboratory yang dikembangkan dapat diterapkan dalam pembelajaran sehingga berdaya guna untuk meningkatkan pemahaman siswa. 


\section{DAFTAR PUSTAKA}

Bintarto, R. (1988). Geografi, Ilmu Dan Aplikasinya: Sebuah Informasi. Majalah Geografi Indonesia, 1(1988).

Hamida, N. Mulyani, B., \& Utami, B. (2013). Studi Komparasi Penggunaan Laboratorium Virtual dan Laboratorium Riil dalam Pembelajaran Student Teams Achievement Division (STAD) Terhadap Prestasi Belajar ditinjau dari Kreativitas Siswa pada Materi Pokok Sistem Koloid Kelas XI Semester Genap SMA Negeri. Jurnal Pendidikan Kimia, 715.

Hasriyanti. (2009). Latihan Pengoperasian Sieve Net dan Analisisnya dalam Praktek Laboratorium untuk Meningkatkan Hasil Belajar Topik Sedimen Dasar Laut pada Mahasiswa Jurusan Geografi Universitas Negeri Makasar. Universitas Negeri Malang.

Jaya, H. (2012). Pengembangan Laboratorium Virtual untuk Kegiatan Praktikum dan Memfasilitasi Pendidikan Karakter di SMK. Jurnal Pendidikan Vokasi, 2(1), 81-90.

Kusumaningsih, Y.R. Iswahyudi, C., \& Susanti, E. (2014). Pengembangan Model Laboratorium Virtual Sebagai Solusi Keterbatasan Sumber Daya Pembelajaran. In Seminar Nasional Aplikasi Sains \& Teknologi (SNAST). Yogyakarta.

Mahanta, \& Sarma, K. (2012). Online Resource and ICT Aided Virtual Laboratory Setup. Journal of Computer Applications, 44-48.

Mukminan. (2014). Tantangan Pendidikan di Abad 21. Universitas Negeri Surabaya.

Munawarah, F. R. (2014). Pemanfaatan Laboratorium IPS Geografi untuk Pembelajaran Geografi SMA di Kabupaten Bantul. Universitas Negeri Yogyakarta.

Musyaddad, K. (2013). Problematika Pendidikan Di Indonesia. Edu-Bio, 51-57.

Nursa'ban, M., Suparmini, \& Setyowati, S. (2012). Evaluasi Kompetensi Pedagogik Guru Geografi SMA di Kabupaten Bantul. SOCIA, 11(2), 165182.
Nurwenda, W., Ningrum, E., \& Yani, A. (2016). Kompetensi Pedagogik Guru Geografi dalam Proses Pembelajaran di SMA Negeri Se-Kabupaten Bandung (Pada Kompetensi Inti Guru dalam Menyelenggarakan Pembelajaran yang Mendidik). Antalogi Geografi, 4(1), 1-12.

Pribadi, B. A. (2010). Model Desain Sistem Pembelajaran. Jakarta: PT. Dian Rakyat.

Purwati, D. Yani, A., \& Haris, A. (2015). Penerapan Media Laboratorium Virtual Dalam Pembelajaran Fisika Di SMA Negeri 2 Sengkang. Jurnal Pendidikan Fisika, 3(1), 57-63.

Putra, N. (2015). Research \& Development. Jakarta: Rajagarafindo Persada.

Suharini, E. (2009). Studi Tentang Kompetensi Pedagogik dan Profesional Bagi Guru Geografi di SMA Negeri Kabupaten Pati. Jurnal Geografi, 6(2), 133-145.

Suharsono, S., \& Budi, T. P. (2006). Penajaman Dan Kejelasan Objek Kajian Dalam Disiplin Ilmu Geografi. Majalah Geografi Indonesia, 20(2), 187201.

Sumargo, E., \& Yuanita, L. (2014). Penerapan Media Laboratorium Virtual (Phet) pada Materi Laju Reaksi dengan Model Pengajaran Langsung. Unesa Journal of Chemical Education, 3(1), 119-133.

Swandi, A., Hidayah, S. N., \& Irsan, L. J. (2014). Pengembangan Media Pembelajaran Laboratorium Virtual untuk Mengatasi Miskonsepsi pada Materi Fisika Inti di SMAN 1 Binamu Jeneponto. Jurnal Fisika Indonesia, 52, 119-133.

Wulandari, L. (2012). Efektivitas Pemanfaatan Laboratorium Geografi dalam Meningkatkan Hasil Belajar Siswa Kelas X SMA Negeri 7 Purworejo. Universitas Negeri Yogyakarta.

Yusriyah, K. (2008). Persepsi Mahasiswa Terhadap Manfaat dan Kemudahan Penggunaan V-Lab Riset Operasional. Jurnal Psikologi, 53-60. 